is now in a position to select the most suitable one for each purpose from the equipment commercially available.

\section{Children in Care}

Until about 1960 the annual numbers of illegitimate births and of marriages ending in divorce in England and Wales had not shown a distinct trend up or down since the peak years immediately after the second world war. Then in 1961 the rates for both rose sharply, and they have continued to do so. In $1965^{1}$ the number of illegitimate babies born was 66,249 , or 77 per 1,000 total live births, and the number of divorces was 37,785 , or 3.1 per 1,000 married population. Since in many cases the welfare of young children is affected, it is no surprise to learn from the latest report of the Children's Department of the Home Office ${ }^{2}$ that between 1959 and 1966 the total number of children in the care of local authorities and voluntarv organizations in England and Wales rose from 78,648 t. 79,995. But some comfort may be taken from the fact that the increase was not greater, for it actually represents a fall from 6.5 to 6.1 per 1,000 of the population aged under 18 .

Illness of a parent and confinement of the mother together provide the main immediate cause of children coming into the care of local authorities; the second largest cause of being taken into care is desertion by the mother. The increase in the latter type of cases from 1963 to 1966 was $31 \%$. More remarkable perhaps is the increase of $81 \%$ (from 1,319 to 2,283 ) in the same period of children taken into the care of local authorities owing to unsatisfactory home conditions. The continual improvement in housing for some years might have suggested that a diminution in this category would have been more probable than such a substantial increase.

Since it is now generally acknowledged that a child is better brought up in a family than in an institutional home, however kindly and carefully run, it is worth noting that children's departments are placing many more children with foster parents than formerly and that the numbers of legal adoptions continue to rise each ycar. Between 1959 and 1965 the number of children adopted annually rose by $50 \%$ from 14,000 to 21,000 . Of the latter total $80 \%$ were illegitimate. In view of the important contribution that adoption is now making to the well-being of a considerable fraction of the population the special problems it poses deserve careful study. This is equally true of the individual case, in which a medical man may be called upon to give an opinion in a variety of circumstances. The pitfalls in trying to assess the future health of very young babies are well known, and they are more numerous than usual when one or both parents are inaccessible, as is a feature of many adoption cases. Some of the special problems have been discussed by J. A. Black and F. H. Stone. ${ }^{3}$ But a doctor's role may extend far beyond an assessment of the child's health and thrust upon him legal as well as medical responsibilities. Of these Hilda Lewis ${ }^{4}$ provided an instructive account.

As the report says, "Far too little is known about what makes for a successful adoption, or indeed about how one

\footnotetext{
1 The Registrar General's Statistical Review of England and Wales for the Year 1965, Pt. 2, Tables, Population, 1967. H.M.S.O.

2 Report on the Work of the Children's Department 1964-1966, Home Office, 1967. H.M.S.O.

- Black, J. A., and Stone, F. H., Lancet, 1958, 2, 1272.

- Lewis, H. N., Brit. med. F., 1965, 2, 577.
}

should measure "success." It might perhaps have said the same of parenthood. However that may be, society must accept a special responsibility to ensure that the adoptive procedures it sanctions are as beneficial as possible. Consequently, the studies of its efficacy sponsored by the Home Office, and briefly mentioned in the report, are to be welcomed.

\section{Sentence Without Trial}

A letter in our correspondence columns (p. 556) draws attention to the case of Dr. Raymond Hoffenberg, senior lecturer in the Department of Medicine at Cape Town University, on whom the South African Department of Justice has recently served a banning order. Professor John F. Brock, head of the department in which Dr. Hoffenberg works and President of the College of Physicians, Surgeons, and Gynaecologists of South Africa, has already strongly condemned the action of the Department of Justice. ${ }^{1}$

Dr. Hoffenberg is a distinguished physician, medical scientist, and teacher at Groote Schuur Hospital, Cape Town, known and consulted internationally for his work on radioisotopes, thyroid function, and protein malnutrition. He was formerly acting chairman of the banned South African Defence and Aid Fund, a body which helped political prisoners. ${ }^{2}$ Two years ago his passport was withdrawn. No charges were made against him, and inquiries by Professor Brock failed to elicit the reason for the withdrawal. Nor recently could he obtain permission for Dr. Hoffenberg to attend, on behalf of his hospital and university, an international atomic energy meeting in Vienna to which he had been invited. Now a five-year banning order has been imposed, again without any charges being made. The ban ${ }^{3}$ restricts Dr. Hoffenberg to the Cape Town area, requires him to report weekly to the police, and prevents him from attending any gathering, social or otherwise, of more than one person. $\mathrm{He}$ is forbidden to publish, and this apparently includes scientific articles. He must give up his academic appointment at Groote Schuur Hospital at the end of this year. In the words of correspondents to The Times," "He is removed from the world of medical science, to which he has made notable contributions; he is expunged from society"-all without trial.

Banning orders have been applied to other citizens of South Africa, but not before, it seems, to a medical man. Many South African doctors are shocked by what has occurred, and the College of Physicians, Surgeons, and Gynaecologists, the South African Medical and Dental Council, and the Medical Association of South Africa are to be asked to report on Dr. Hoffenberg's case.

By its actions the Department of Justice has effectively deprived the world of medicine, abroad as well as in South Africa, of the services of a distinguished doctor. No research worker can hope to maintain his impetus without freedom to associate with colleagues, to travel, and to publish his findings. It concerns the profession everywhere that any State, without charge or trial, should thus excommunicate a doctor from his professional life. South Africa will damage only its own reputation if it persists in penalizing Dr. Hoffenberg without a fair hearing.

\footnotetext{
1 Cape Times, 2 August 1967.

2 The Times, 4 August 1967.

- Sunday Times, 6 August 1967.

The Times, 17 August 1967.
} 